\title{
Factors Affecting Dividend Payment Decisions: The Case of Libya
}

\author{
Akram Budagaga \\ Warsaw School of Economics (SGH) - Poland
}

\begin{abstract}
This research paper will investigate the views of executives and top management of firms listed on the Libyan Stock Market [LSM] regarding the main factors affecting dividend payment decisions. A questionnaire has been used to gather primary data from a range of industries. The evidence reports that the most influential factors in making dividend payment decisions involve: earnings [level of current earnings], Patterns of past dividends, investment opportunities, and liquidity [availability of cash]. Furthermore, the viewpoints of the respondents from three industry sets show no difference in the importance of the dividend factors among industries groups, except the level of reserve. Therefore, the industry type issue appeared to influence the importance that respondents placed on determinants of dividend payment decisions. The findings also show that respondents strongly believe that dividend payment is an important issue in Libyan firms, and these results are consistent with signaling and Pecking order explanations for paying cash dividends. The originality of this paper lies in presenting new evidence to the body of knowledge regarding dividend decisions in a pre-emerging market; this is the first study to document the perceptions of managers of dividend-paying LSM-listed firms about the factors affecting dividend payments.
\end{abstract}

Keywords: Dividend decisions, Factors, Libyan firms.

\section{INTRODUCTION}

Dividend decisions have been a contentious issue in financial literature for many decades, and remain the greatest dilemma for both academics and practitioners.

Ample empirical studies have attempted to highlight this issue from different perspectives and have followed various approaches to identify the fundamental factors that affect dividend decisions. According to Baker et al. [2015], the main reason for this continual debate is the extensive research that has adopted the economic modeling approach describing the factors behind dividend decisions. Relying on this approach alone, however, to merely model market data while neglecting behavioral approaches which measure how managers behave when making such decisions cannot completely identify factors affecting dividend payment decisions. Chiang et al. [2006,p.78] deduced that the cardinal thrust of academic research must turn toward learning about motivation and on what perceptions this motivation is based.

Due to dividend behavior being "a cultural phenomenon" [Frankfurter and Wood,1997, p. 31], dividends policy in pre-emerging markets is significantly different from that in advanced markets[characterized by higher degrees of efficiency, competitiveness and liquidity, and by having greater transparency]. Libya is a pre-emerging economy in which the stock market has only recently been established and most of its listed firms are in state-ownership. Added to that, some firms were only privatized in the last few years, and these facts will undoubtedly influence respondents' views.

In light of the limited number of studies on dividend policy in developing economies in general, and the issue of dividends from the recently established Libyan Stock Market [LSM] in particular, this paper has three aims. The primary aim is to identify the most influential factors 
used by Libyan firms that trade on the Libyan Stock Market in making dividend payments decision. The second aim is to determine whether the factors affecting dividend payment decisions differ from one industry to another. The final aim of this study is to learn the views of executives and top management in Libyan firms about importance of the dividend payments decision. To accomplish these aims, a survey was employed to collect data directly from decision makers in Libyan listed firms. The contribution of this study lies in providing valuable insights on dividend payments from pre-emerging market.

The remainder of this paper is organized as follows: in the second section, the researcher briefly describes the history of the Libyan Stock Market; the third section provides literature review; the fourth section configures theoretical framework and hypotheses development; the fifth section introduces the research methodology and sample, followed by the results of the survey and discussion. Finally, it draws a conclusion.

\section{BACKGROUND OF LIBYAN STOCK MARKET}

The Libyan Stock Market [LSM] is a recent innovation, founded in 2006 with a capital of 400 million Libyan dinars. At that time, only seven firms were listed on the main table in the stock market and trading was minimal. In addition, the majority of shareholders were employees in their firms. The main active sectors in the LSM are banking and insurance, along with a small number of manufacturing firms. The most important sectors in the Libyan economy, however, such as oil, telecommunications and agriculture are absent. In 2007, the limitations of hand trading restricted LSM trading levels, but in April 2008 the market started using electronic trading with an opening index of 1000 points [ Aljbiri, 2012].From that time the number of firms listed on the main table increased gradually to reach ten firms and a sub-table of fifteen by the beginning of 2009.During that year the number of firms rose to 25 on the main table, with 41 firms in 2010 in two tables [ Edweib et al., 2012].

The total number of investors registered in the market reached around 250,000 investors and in 2010 the average daily trading value was 304,005 LD [according to Libyan Central bank $1 \$=$ $1.24 \mathrm{LD}$ ] with about 7,465 transactions. There were 12 listed brokerage companies in 2008,rising to 25 in 2010. However, from 22 ${ }^{\text {nd }}$ February, 2011,five days after the start of the Libyan Civil War, the market closed for one full year, reopening on $22^{\text {nd }}$ February 2012 . This closure led to the delay in the performance of the market [op.cit.,2012, p. 46].

\section{LITERATURE REVIEW}

The corporate financial literature contains voluminous research studies, including surveys dating back more than half century. It presents a large number of theories, hypotheses, and explanations for the dividends policy. In this section, two main topics will be discussed. First, explanations for paying cash dividends. Second, the main survey studies on dividends policy.

\section{explanations for paying cash dividends}

Many of the dividend theories that are commonly discussed today were originally proposed in literature in an attempt to explain the reasons for paying dividends. Below are eight broad categories, which are not necessarily mutually exclusive, for paying

cash dividends:

1- Bird in hand theory: the theory claims that due to the uncertainty associated with the business environment, investors prefer current dividend payments as a bird in hand rather than capital gains as a sparrow in the tree because of lower risk [Gordon, 1959, 1963; Bhattacharya, 1979].

2- Information signalling theory: the theory argues that there is a gap between managers and investors, this gap can be reduced via dividend payments, therefore, investors 
consider an increase in dividend payments as a positive signal for a firm's future profits and its promising performance [Bhattacharya, 1979, 1980; John and Williams, 1985].

3- Agency cost theory: the theory proposes that due to separation between ownership and management, the dividend payment is a useful way for lowering the agency cost of free cash flow [ Jensen and Meckling, 1976; Easterbrook, 1984; Jensen, 1986].

4- Transaction cost theory: this theory posits that firms have limited internal fund resources to finance their investment needs, therefore, the firms pay low or nondividends to avoid the transaction cost associated with dividend payments and external financing [Rozeff, 1982].

5- Tax-related effect theory: the supporters of this theory believe that dividend payments are taxed more than capital gains, thus, managers of firms should retain earnings [no dividend payments] and transfer them to capital gains [Elton and Gruber, 1970; Miller and Scholes, 1978, 1982].

6- Pecking order theory: the theory claims that the priority to financing investment opportunities must be via internal cash flow, then debt and finally equity issuance. Therefore, firms should adopt a low dividend policy [Myers,1984; Myers and Majluf,1984].

7- Life cycle theory: the theory assumes that a young firm in its high growth phase has many positive investment options but limited cash flow, therefore no dividend payments. While mature firms have a large amount of free cash flow but poor of investment opportunities, as a result, paying high dividends ratio [Fama and French, 2001; DeAngelo et al., 2006].

8- Catering theory: this theory argues that investors' decision about dividend is determined by their sentiment which inconstant over the time, thus, managers of firms cater to investors what they currently require [Baker and Wurgler, 2004].

\section{Survey Studies on dividends}

financial scholars have attempted to identify the main factors affecting dividend payment decisions employing survey approach. For instance, Lintner [1956] is best known for using a behavioral approach to ascertain the views of managers regarding determinants of dividend policy. He found that the most important determinants of dividends are the stability of earnings in the case of young firms, the long-term target payout of dividends, and current earnings.

Baker and Powell [2000] investigated the views of managers of NYSE-listed US firms about factors determining dividend policy. Their study updates and extends previous survey research on dividends policy and provides a longitudinal comparison for the years1983-1997. They conclude that the most important factors include the level of current earnings, the level of expected earnings, and the pattern of past dividends. The key factors remain stable over the time period; however, industry type appeared to influence the importance that respondents placed on some determinants of dividend policy. Baker et al. [2001] examined the perception of managers about twenty-two factors [based on results from a 1999 survey] that influence dividends policy of financial and non-financial firms listed on NASDAQ. Their findings showed that the most important factors are the pattern of past dividends, the stability of earnings, and the level of current and expected future earnings. The study also identified significant differences between managers of financial firms and non-financial firms attached to nine of 22 factors in terms of importance. Frankfurter et al. [2004] carried out research in five countries on three continents to discover the perception of chief financial managers about dividends payout. They concluded that culture dimensions play a vital role in the perception of dividends policy. 
Brav et al. [2005] employed surveys and in-depth interviews with the executives of 384 public and private firms in the US to identify factors that affect dividend payouts and repurchase of shares. Their findings suggest that the target payout is no longer a preeminent decision variable and that managers express a strong desire to avoid cutting dividends and only consider increasing the level of dividends after investment and liquidity needs, and the requirements for stable future earnings are met. Bancel et al. [2005] surveyed the managers of 1131 firms in 16 European countries to find out determinants of dividend payouts in order to compare their views with those of US managers. The results showed that smooth dividends and the difficulty in cutting dividends are the most important factors. The study also revealed that although the European and American managers followed different targets, their views were similar.

Baker et al. [2006] conducted a study of Norwegian firms listed on the Oslo Stock Exchange to establish the views of Norwegian managers regarding the most important factors in making dividend decisions and to compare Norwegian managers' views with those of American managers in terms of the key factors. The study revealed that the most important factors influencing dividend decisions related to earnings, specifically current and expected future earnings, as well as the stability of earnings. Other significant determinants of dividend payments include the current degree of leverage and liquidity constraints. The study also found that managers of Norwegian firms view legal rules and constraints as more important than do their U.S. counterparts. By contrast, managers of U.S. firms rank the pattern of past dividends as more important than do managers of Norwegian firms.

Baker et al. [2007] analyzed survey results which looked into the perception of managers of 291 firms listed on the Toronto Stock Exchange about dividends policy. They deduced that the level of current and expected future earnings, the stability of earnings and the patterns of past dividends are the main factors affecting dividend payouts. This indicates that Canadian managers' views are similar to those of US managers.

Mizuno [2007] investigated the perception of managers of four industries listed on Tokyo Stock Exchange about dividend payout policy. The results reported that the stability of dividends is the key factor and a high proportion of respondents agreed that dividends should be paid after investment spending and strength of the balance sheet are met. Archold and Vieira [2010] conducted a study on 313 financial firms listed in the UK and 48 listed in Portugal to find out the viewpoints of financial directors about determinants of dividend decisions. The findings showed that respondents strongly believe that stability and sustainability of future earnings are the most important factors influence dividend decisions. Baker et al. [2012] investigated factors that lead to the decision of Canadian managers not to pay cash dividends. The evidence showed that growth, expansion opportunity, low profitability and cash constraints were deciding factors. The results also suggest that taxation is at best secondary as a determinant of dividends.

Although empirical research on dividend payment is extensive, the vast majority of studies have been conducted in devolved countries, primarily the United States, and little is known about dividend behavior in developing countries. Al Deehani [2003] examined top managements' views about determinants of dividend policy in Kuwait as a small emerging market. Results of a questionnaire distributed to 41 firms listed on the Kuwait Stock Exchange suggested that clientele effect motives are the most important factors in all sectors, while signaling is the most important for some sectors. Pourheydari [2009] investigated the perception of chief financial officers about determinants to dividend policy of 111 Iranian firms listed on the Tehran Stock Exchange. The findings reported that stability of cash flow, 
availability of profitable investment opportunity and continuity of past dividends are the most important factors. Industry type also appeared to influence the importance that respondents placed on one determinant of dividend policy.

El Sady et al. [2012] investigated managers' views of 185 firms listed on the Kuwait Stock Exchange. They found that the level of current and future earnings, liquidity constraints, and availability of the positive present value project are the most important factors affecting dividends policy. Baker and Powell [2012] conducted a study of 163 firms listed on the Indonesian Stock Exchange and results showed that the most important factors involve the stability earnings, the level current earnings, expected future earnings, and liquidity constraints.

John [2013] investigated the perception of managers from 30 firms listed on the Nigerian Stock Market to discover factors that impact on dividend payouts. He determined that the level of current earnings, the current degree of financial leverage, the availability of an alternative source of capital, liquidity constraints and investment opportunities have a significant impact on dividend payouts. Naser et al. [2013] examined the opinions of managers of firms listed on Abu Dhabi securities about determinants of dividends. They found that the most important factors are, respectively, the pattern of past dividends, and the stability of earnings and expected earnings. Baker and Kapoor [2015] surveyed managers of dividend-paying firms listed on the National Stock Exchange [NSE] in India and revealed that the most important determinants of dividends involve earnings [the stability of earnings as well as the level of current and expected future earnings] and the pattern of past dividends.

Baker and Jabbouri [2016] surveyed the perception of managers of Moroccan firms listed on the Casablanca Stock Exchange to discover their opinion about determinants of dividend policy, dividends issue and explanation of paying dividends. The results show that the level of current earnings, stability of earnings and the needs of current shareholders are the most important factors influencing dividends policy.

\section{THEORETICAL FRAMEWORK AND HYPOTHESES DEVELOPMENT}

Based on the literature review and the researcher's knowledge of the Libyan economic environment in respect to the recent development of the LSM, the lack of public awareness of dividends, and the lack of adequate financial disclosure, the researcher speculates that the following factors play a vital role in dividend payment decisions of Libyan listed firms.

\section{Earnings [Profitability]}

There is almost unanimous agreement in the financial literature that profitability of firms is one of the most significant factors impacting on dividend payment decisions [Baker and Powell,2000 ; Fama and French, 2000,2002; Baker et al., 2006;Denis and Osobov, 2008;El Sady et al., 2012; Hossain et al., 2014].Since the amount of dividend is often distributed from annual income, it can be argued that more profitable firms have a tendency to increase their dividend payments. Bhattacharya [1979], Miller and Rock [1985] Asquith and Mullins [1983, 1986] and Baker, Mendel and Wurgler [2015] explained higher dividend payment as a strong signal of future cash flow; because, management of firms [insiders] are likely to have more private knowledge about current situations and bright future prospects than investors [outsiders],managers use dividends as a device to convey useful information to the financial market about future profitability and growth, which in turn reduces asymmetric information [John and Williams, 1985].However, the question emerges: are dividend decisions motivated by current, future or stability of earnings? Several studies conducted in advanced and 
emerging markets reported that the largest factor influencing dividend decisions is the level of current earning [Linter,1956;Baker and Powell,2000;Baker et al., 2007;John, 2013;Alzomaia\& Al-Khadhiri, 2013]. These studies claim that cash flow [current earnings] reflects the ability of firms to pay dividends.

The expected future earning is also, categorized as a key factor that affect dividends decision [Baker \& Powell, 2000;Baker et al., 2001;Brav et al., 2005;Baker et al.,2007;Baker \&Jabbouri,2016].The importance of this factor stems from the stability of future cash flow. Babiak and Fama [1968] found that managers have an aversion to increasing dividends which cannot be compensated by future earnings.

As such, the stability of earnings is documented as the main factor in deciding on dividends payment [Pourheydari, 2009;Archold and Vieira, 2010;Baker and Powell,2012;Baker and Kaboor,2015; Baker and Jabbouri, 2016].This suggests that managers recognize the importance of maintaining the magnitude of cash dividend from reducing in the future. The higher the volatility of earnings, the greater the likelihood is that a firm will experience a decrease in earnings which could result in a forced decline in the cash payouts [Baker et al., 2001]. Accordingly, the hypotheses are formulated as follows :

Hypothesis 1: Ceteris paribus, Earnings significantly affect dividend payment decisions in Libya: Hypothesis 1A: Ceteris paribus, Level of current earnings significantly affects dividend payment decisions in Libya.

Hypothesis 1B: Ceteris paribus, Level of expected future earnings significantly affects dividend payment decisions in Libya.

Hypothesis 1C: Ceteris paribus, Stability of earnings significantly affects dividend payment decisions in Libya.

\section{Pattern or Continuity of Past Dividends}

Patterns of past dividends play a vital role in setting dividends policy; firms tend to keep cash dividends at least at the previous year's level. The earliest study was undertaken by Linter [1956] who suggested that firms' payout patterns depend on the dividends of the previous period. He argued that managers believe investors prefer firms which follow a steady dividends payout ratio, thus firms avoid changing dividend rates and try to maintain a constant level of dividend payouts. Brittan [1966] applied Linter's model and confirmed that firms follow a Constant Payout Ratio Policy. Similarly, Shevlin [1982] examined Linter's dividends model on a sample of Canadian and Australian firms, and the results suggested that dividend decisions depend on past patterns of dividends. Many other studies assert Linter's findings that past dividend patterns influence dividend payment decisions [Baker et al., 1985; Pruitt and Gitman, 1991;Benartzi et al., 1997; Baker et al.,1999;Benzinho, 2004;Bancel et al., 2005; AlTwaijry,2007;Mizuno,2007;Szomko, 2015].

Conversely, Glen et al. [1995] argued that the behavior of dividends policy in developing countries is different from that in developed countries. They contend that dividend decisions in emerging markets are unrelated to past patterns of dividend payouts. Frankfurter and Wood [1997] deduced that patterns of firms' dividend payouts are a cultural phenomenon. More recently, Khan [2011] revealed that Pakistani managers do not take into account past patterns of payouts when setting dividends policy. Rahaman [2015] investigated the perception of 124 chief financial officers of firms listed on the Dhaka Stock Exchange [DSE] of Bangladesh. He found that target payout ratio follows current earnings and patterns of dividends changes over a firm's life cycle. ]. Accordingly, the hypothesis is formulated as follows :

Hypothesis 2: Ceteris paribus, Pattern of past dividends significantly affects dividend payment decisions in Libya. 


\section{Investment Opportunities}

Since early research into the dividends phenomena, firms' financing needs for investment intentions have been addressed in many studies as a leading determinant of dividends policy [Miller and Modigliani,1961; Higgers,1972;Macabe, 1979]. A review of financial literature discloses several explanations in regard to the correlation between investment opportunities and dividend payouts. For instance, the residual theory suggests that after all profitable investment opportunities have been undertaken, the surplus amount distributes as dividends. In this context, firms will totally depend on internally generated funds for growth opportunities; thus, dividend payouts will be low and often zero. Miller and Modigliani [1961] confirm that firms pay cash dividends after exhausting all profitable investments. More recently, focusing on emerging markets, Baker and Jabbouri [2016] surveyed Moroccan managers about setting dividends policy and found that $54 \%$ of respondents believed firms should pay dividends only after financing future investment opportunities and those managers generally support a residual theory.

Another explanation can be seen in life cycle theory which assumes that firms in advanced stages tend to pay higher dividend payments, while firms in the early phases of development retain earnings for new investments [Grullon et. al., 2002;DeAngelo and DeAngelo,2006].The logical notion of this assumption is that young firms have many positive investment opportunities with limited funding resources; thus, firms are forced to hold onto earnings rather than pay dividends. Fama and French [2001] revealed that firms with low growth options tend to pay higher dividend ratios, while high growth firms resort to keeping profits for new projects. Other studies documented that investment opportunities affect dividend decision [Chang and Rhee,1990; Smith and Watts, 1992;Holder et al., 1998]. Further, the pecking order theory, presented by Myers [1984] and Myers and Majluf [1984] claims that firms fund their projects and expand according to a particular order: first, internal funds [retained earnings]; second, external financing [debt] short-run over long run; and finally, equity issuance. In this respect, rapidly growing firms finance future profitable investments via external funds [if financing requirements for growth opportunities exceed internal resources]; thus, firms are more likely to pay low or no dividends. Therefore, the hypothesis is formulated as follows :

Hypothesis 3: Ceteris paribus, Investment opportunities significantly affect dividend payment decisions in Libya.

\section{Current Degree of Financial Leverage}

Financial leverage has been considered as a primary factor that affects dividend decisions [Crutchley and Hansen,1989;jensen et al., 1992;Gugler and Yurtoglu, 2003;Aivazian et al., 2003; Al Malkawi,2005; Al Twajiry, 2007;Al Kuwari, 2009]. Leverage is defined by Ward and Price [2006] as the percentage of capital that is financed by external funds [debt] instead of equity.

Numerous explanations can be found in financial literature about the main reasons for making firms pay low dividends. For instance, firms with high financial leverage tend to decrease dividend payouts due to constraints of debt-suppliers which impose rules upon the firms to maintain internal cash to cover financial obligations toward debt providers [Agrawal \& Jayaraman, 1994; Manos, 2003; Naser et al., 2004; Rahaman, 2015]. In other words, highly leveraged firms have fixed financial commitments [interest payments] stemming from external debt. In such cases, firms will resort to retain internal cash resources to meet these liabilities towards creditors, and failure to meet these obligations may result in bankruptcy. Rozeff 
[1982] revealed that firms with a high level of debt tend to pay low dividends to avoid the transaction costs associated with external financing.

Other literature suggests that debt can be used as a device to reduce agency costs of free cash flow. Jensen [1989], Jensen \& Meckling [1976], and Myers [1977],among others, argue that debt is another mechanism to minimize the agency problem of free cash flow; that is, when a firm borrows money, it will bear a large burden of fixed costs towards the lender, which will put management under control and monitoring in order to meet these commitments, and thus avoid keeping large free cash flow in the firms and, as a result, mitigate agency costs [risk of waste free cash flow] and maintain lenders' confidence. Hence, the hypothesis is formulated as follows :

Hypothesis 4: Ceteris paribus, Level of current financial leverage significantly affects dividend payment decisions in Libya.

\section{Liquidity Constraints}

Liquidity has been described in financial literature as a major factor influencing dividends policy [Alli et al.,1993; Ho,2003;Kanwal and Kapoor, 2008; Baker et al., 2012; Kumar and Waheed, 2015]. The reason for the importance of this factor is that a strong liquidity position indicates [signals] the extent to which a firm is able to meet its financial obligations. Firms with higher cash availability tend to distribute higher cash dividend ratios as compared to firms with a poor liquidity. Baker, Mukherjee and Paskelian [2005] interpreted the importance of liquidity in affecting dividend payment decisions, suggesting that paying cash dividends depends on cash availability, not on earnings based on accrual accounting. As a result, the availability of cash has a crucial impact on the ability of firms to pay cash dividends. Forti et al. [2015] concluded that a large liquidity position correlates with larger firms' propensity to pay dividends to shareholders. Therefore, , the hypothesis is formulated as follows :

Hypothesis 5: Ceteris paribus, Liquidity significantly affects dividend payment decisions in Libya.

\section{Legal Rules and Constraints}

Legal restrictions such as capital requirements influence the amount that firms payout as dividends to shareholders [Mayne, 1980; Boldin and Leggett, 1995; Baker et al., 2001; Baker et al.,2006]. Cash dividend payments should not be greater than the total of retained profits plus net income for the current fiscal year. This so-called capital impairment rule prohibits the distribution of annual profits in cases of impairment of capital [Ballantine \& Hills, 1935, p. 246].

Laws and regulations affect the process of setting dividend payout policy. For instance, the Basel Committee on Banking Supervision [BCBS, 2011] points to the increasing regulatory relevance of banks' dividend policy [Brunnermeier et al., 2009]. Mehta et al. [2014] conducted research on determinants of banks' dividend policies in Pakistan. They revealed that the level of reserves has a major impact on dividend payments. Hsia and Tseng [2016] found that capital requirement regulation has a significant impact on banks' dividend payouts. Accordingly, , the hypotheses are formulated as follows :

Hypothesis 6: Ceteris paribus, Legal rules and constraints significantly affect dividend payment decisions in Libya:

Hypothesis 6A: Level of reserves significantly affects dividend payment decisions in Libya. Hypothesis 6B: Impairment of capital significantly affects dividend payment decisions in Libya.

\section{METHODOLOGY AND DATA SAMPLE}

This study adopted the quantitative approach, and employs a survey as the primary means of collecting data, similar to that used in many previous studies [Baker and Powell 2001; Brav et 
al. 2005; Baker et al. 2012, 2015 and 2016]. The survey [questionnaire] is designed with two pages which translate text from English to Arabic [a copy of the Arabic version is available from the author] and consists of three sections: the first section contains four questions that provide a profile of respondents. The second section concerns specific information to identify whether dividend payment decisions are important in Libyan firms and if the respondents took part in dividend payment decisions during their career. The third section contains 11 closedend statements to obtain information about firm dividend policy. The section asks respondents to indicate the importance of 11 factors that each firm used in determining its dividend policy.

These main factors were derived from literature and previous empirical studies on dividends. A five-level Likert scale was used :[1= very un-important, $2=$ un-important, $3=$ neither important nor unimportant, $4=$ important and $5=$ very important]. The questionnaire also contains open questions which give respondents a chance to provide information about any other factors which might affect their dividend payment decisions. The questionnaire was piloted by academic colleagues and their feedback was used to make modifications before the final version of the questionnaire was given to the survey group.

Using the Libyan Stock Market [LSM] web page, the researcher selected listed firms which met one criterion: having paid cash dividends in two years during [2009-2015].To confirm this criterion, financial statements of the firms were viewed. The sample contained 36 firms ${ }^{1}$ from three industries [banking, insurance, and manufacturing].The questionnaires were distributed to the board of directors, chief executives and chief accountants of each firm ${ }^{2}$. Each questionnaire was presented with a cover letter which informed potential respondents that the result would be anonymous and published in summary. The 93 questionnaires were distributed in mid-April, 2016. By the end of July 2016, 80 responses had been received, but only 77 of these were usable [83\% responses rate]. Summary information is presented in table [1]:

Table 1. Numbers and percentages of responses

\begin{tabular}{|c|c|c|c|c|c|c|c|c|}
\hline & \multicolumn{2}{|c|}{ Banking Firms } & \multicolumn{2}{|c|}{ Insurance Firms } & \multicolumn{2}{|c|}{$\begin{array}{l}\text { Manufacturing } \\
\text { Firms }\end{array}$} & \multicolumn{2}{|c|}{ Total } \\
\hline & Numbers & $\%$ & Numbers & $\%$ & Numbers & $\%$ & Numbers & $\%$ \\
\hline $\begin{array}{c}\text { Questionnaire } \\
\text { distributed }\end{array}$ & 35 & $\% 38$ & 18 & $\% 19$ & 40 & $\% 43$ & 93 & $\% 100$ \\
\hline Received & 28 & $\% 35$ & 16 & $\% 20$ & 36 & $\% 45$ & 80 & $\% 86$ \\
\hline Usable & 28 & $\% 36$ & 16 & $\% 21$ & 33 & $\% 43$ & 77 & $\% 83$ \\
\hline
\end{tabular}

STATISTICS TESTS

Several statistical tests using SPSS software were conducted in order to analyze data collected from the questionnaires to achieve the aim of the study. The descriptive statistics used to show

\footnotetext{
1 The sample included all firms that publish their financial statements regularly during the study period.

${ }^{2}$ Due to the difficulty of using the mail system in Libya, the researcher recruited a team of three people (one person for each industry) to hand out and collect the questionnaires, which in turn led to increasing the response rate.
} 
whether respondents agree with the importance of the dividend payment issue in Libyan firms, and if respondents took part in dividend decisions during their career as well as the factors that influence the dividend policy, considered by managers in setting their firm's dividend policy. The researcher used the sign tests to determine the influence of each factor on the dividend policy of the firms paying dividends. Chi-square $\left[X^{2}\right]$ analysis was used to test for the differences in responses among three industry groups, regarding 11 factors influencing dividend policy.

\section{LIMITATIONS}

As with any survey, some potential limitations of this study should be noted. First, the study concentrated only on the main factors [depending on results from prior empirical studies] affecting dividend payment decisions because these factors are familiar to decision makers of Libyan firms: the recent establishment of Libyan Stock Market; the lack of public awareness of the issuing of dividends; inadequate disclosure; and absence of effective financial intermediaries. Second, the researcher restricted the sample to three industries represented on the LSM. Third, the survey methodology measured beliefs and not necessarily actions. Finally, the researcher limited the length of the survey to increase the responses. Therefore, caution should be taken in generalizing the results.

\section{SURVEY FINDINGS AND DISCUSSION}

This section provides respondents' views concerning the importance of dividend payment decisions, the factors [in the Libyan context] affecting dividend payment decisions, the most important factors affecting dividend decisions, and industry influence on dividend decisions. This information will be followed by a discussion of the results.

\section{Specific Information about Dividends}

This section highlights whether respondents agree with the importance of the dividend payment issue in Libyan firms, and if respondents took part in dividend decisions during their career. As shown in table [2], 81\% of respondents agree with the importance of the dividend payment issue, while only $19 \%$ do not agree. This result indicates that a high proportion of respondents are aware of the importance of dividend payments despite the fact that the dividend payment issue is a new development in Libya. Add to that, around $87 \%$ of respondents have been involved in dividend payment decisions. The Summary information is presented in table [2].

Table 2. Percentage of agreement about importance dividends issue and Participation of respondents in dividend payment decisions.

\begin{tabular}{|l|c|c|c|c|c|c|c|c|}
\hline \multirow{2}{*}{ Statement } & \multicolumn{2}{|c|}{$\begin{array}{c}\text { Banking } \\
\text { Firms }\end{array}$} & \multicolumn{2}{c|}{ Insurance Firms } & \multicolumn{2}{c|}{$\begin{array}{c}\text { Manufacturing } \\
\text { Firms }\end{array}$} & \multicolumn{2}{c|}{ Total } \\
\cline { 2 - 9 } & Yes & No & Yes & No & Yes & No & Yes & No \\
\hline $\begin{array}{l}\text { Is dividend payment } \\
\text { issue important in } \\
\text { your firm? }\end{array}$ & $\% 75$ & $\% 25$ & $\% 81$ & $\% 19$ & $\% 88$ & $\% 12$ & $\mathbf{\% 8 1}$ & $\% 19$ \\
\hline $\begin{array}{l}\text { Have you ever taken } \\
\text { part in dividend } \\
\text { payment decisions in } \\
\text { your firm? }\end{array}$ & $\% 89$ & $\% 11$ & $\% 87$ & $\% 13$ & $\% 85$ & $\% 15$ & $\% 87$ & $\% 13$ \\
\hline
\end{tabular}

\section{Factors Affecting Dividend Payment Decisions}

This section focus on two areas: which factors are affecting dividend payment decisions and Which the most important factors affecting dividend decision. 
Depicted in Table 2 the descriptive statistics showing the factors that affect dividend payment decisions, considered by managers when setting their firm's dividend policy. The sign tests has been used to determine the effect of each factor on the dividend payment decisions.. In total, factors were statistically significant at 0.001 levels [H1-H1a, H1c-H2, H4-H5, H6, H6a, and H6b] and one factor at the 0.05 level [H3]. The factors that were rejected were: H1b [Level of expected future earnings affects dividend payment decisions of firms].

Table 2 also presents the significance level of each of 11 factors. The following discussion focuses only on the five most important factors affecting the dividend policy. In total, 10 factors were important in affecting dividend policy. The factors were clearly ranked and the highest one was for earnings, specifically "level of current earnings" affects payment dividend decisions [H1a], which reflects the strong relationship between cash flow and dividend payment decisions.

Table 2: factors affecting dividend payment decisions.

\begin{tabular}{|c|c|c|c|c|c|c|c|c|c|c|}
\hline \multirow[b]{2}{*}{ Statements } & \multirow[b]{2}{*}{$\mathbf{H}$} & \multicolumn{5}{|c|}{ Level of importance } & \multirow[b]{2}{*}{ Mean } & \multirow[b]{2}{*}{ Rank } & \multirow[b]{2}{*}{ Std } & \multirow[b]{2}{*}{$\begin{array}{l}\text { Median } \\
\text { Sample }\end{array}$} \\
\hline & & 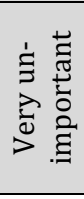 & 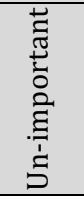 & 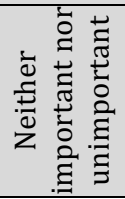 & $\begin{array}{l}\stackrel{\Xi}{\Xi} \\
\stackrel{\varpi}{\Xi} \\
\stackrel{0}{\Xi}\end{array}$ & 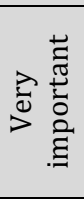 & & & & \\
\hline $\begin{array}{l}\text { Earning affects dividend payment } \\
\text { decisions of firms }\end{array}$ & H1 & 3.3 & 6.7 & 3.0 & 38.6 & 48.4 & 4.31 & 2 & 0.91 & $* * 4$ \\
\hline $\begin{array}{l}\text { Level of current earnings affects } \\
\text { payment dividend decisions }\end{array}$ & H1a & - & - & 0.9 & 38.1 & 61 & 4.58 & 1 & 0.52 & $5 * *$ \\
\hline $\begin{array}{l}\text { Level of expected future earnings } \\
\text { affects dividend payment decisions of } \\
\text { firms }\end{array}$ & $\mathrm{H} 1 \mathrm{~b}$ & 25 & 38.8 & 7.8 & 18.5 & 10 & 2.57 & 11 & 1.43 & 3 \\
\hline $\begin{array}{l}\text { Stability of earnings affects dividend } \\
\text { payment decisions of firms }\end{array}$ & $\mathrm{H} 1 \mathrm{c}$ & 10.6 & 10.5 & 9.2 & 38.6 & 31 & 3.66 & 6 & 1.33 & $4 * *$ \\
\hline $\begin{array}{l}\text { Patterns of past dividends affects } \\
\text { dividend payment decisions of firms }\end{array}$ & $\mathrm{H} 2$ & 7.2 & 9.5 & 12.9 & 34.6 & 34.1 & 3.91 & 3 & 1.13 & $4 * *$ \\
\hline $\begin{array}{l}\text { Investment opportunities affect } \\
\text { dividend payment decisions of firms }\end{array}$ & H3 & 22.9 & 21.4 & 6.6 & 24.9 & 24.3 & 3.88 & 4 & 1.54 & $3 *$ \\
\hline $\begin{array}{l}\text { Level of current financial leverage } \\
\text { affects dividend payment decisions of } \\
\text { firms }\end{array}$ & $\mathrm{H} 4$ & 14.9 & 12.6 & 10.1 & 38.1 & 26 & 3.40 & 8 & 1.43 & $3 * *$ \\
\hline $\begin{array}{l}\text { Liquidity [the availability of cash] } \\
\text { affects dividend payment decisions of } \\
\text { firms }\end{array}$ & H5 & 8.6 & 10.3 & 7.5 & 34.8 & 38.8 & 3.87 & 5 & 1.26 & $3 * *$ \\
\hline $\begin{array}{l}\text { Legal rules and constraints affect } \\
\text { dividend payment decisions of firms }\end{array}$ & H6 & 3.9 & 12.5 & 9.3 & 35 & 39.4 & 3.05 & 10 & 1.19 & $4 * *$ \\
\hline $\begin{array}{l}\text { Level of reserves affect dividend } \\
\text { payment decisions of firms }\end{array}$ & H6a & 15.7 & 10.5 & 12.9 & 31.9 & 29 & 3.30 & 9 & 1.48 & $3 * *$ \\
\hline $\begin{array}{l}\text { Impairment of capital affects } \\
\text { dividend payment decisions of firms }\end{array}$ & $\mathrm{H} 6 \mathrm{~b}$ & 5.9 & 17 & 12.7 & 32.6 & 31.8 & 3.62 & 7 & 1.27 & $4 * *$ \\
\hline
\end{tabular}

Notes: ${ }^{* *}$ and ${ }^{*}$ Significant at the 0.001 and 0.05 levels, respectively. The descriptive statistics show the level of importance of various factors considered by managers in setting their firm's dividend policy. The sign test are used to determine the significance of the each factor. 
The next important factor was Patterns of past dividends affects dividend payment decisions of firms [H2]. The importance of this factor may mean that a firm's past dividend decisions may restrict its current decisions. Baker et al. [1985] found a strong relationship between past and current dividend decisions.

The fourth important factor in setting the firm's dividend policy was investment opportunities affect dividend payment decisions of firms [H3]. Baker and Powell [2000] found a link between investment opportunities and dividend payment decisions.

The fifth most highly-ranked factor influencing dividend policy was liquidity or "availability of cash" [H5]. The findings indicate that firms with higher liquidity pay dividends which convey a positive signal to outsiders that they are able to readily pay its liabilities; this is consistent with the signaling theory explanation for paying dividends.

\section{Industry Affecting Dividend Payout}

This section discusses whether factors affecting dividend payment decisions differ by industry type.

In order to determine the differences in responses among three industry groups, regarding 11 factors affecting dividend payment decisions $X^{2}$ test was employed. To perform the test and avoid inadequate cell size, the researcher collapsed five interval importance scales in two classes. The first class contains very unimportant, unimportant, and neither important nor unimportant; and the second class included important, and very important. The findings suggest that there are no significant differences in the importance of the dividend factors among the three groups, except for the level of reserves factor [H6a).

Further $X^{2}$ test was performed using pair-wise comparisons between the industry groups on all 11 factors. The findings show that the manufacturing and insurance firms had no significant differences in responses at the .05 level for 11 questions with adequate cell sizes. Hence, the differences occurred primarily as a result of the banks' responses relative to either manufacturing or insurance firms.

The reported differences between the banks and the other firms may be due to regulation. Banks, for instance, pay careful attention to "reserves for non-performing loans" because, by law and regulations imposed by the central bank of Libya, they must meet specific [level of reserve] requirements for absorbing any future loan losses. Thus, the executives and top management of banking firms agree about the impact of the level of reserves on dividend payment decisions, whereas the executives and top management of manufacturing firms and insurance firms disagree about the impact of the level of reserves on dividend payment decisions. The Summary information is presented in table [4]. 
Table 4. Differences among firms [industries] about main factors affect dividend payment decisions.

\begin{tabular}{|l|c|c|}
\hline \multicolumn{1}{|c|}{ Statement } & $\begin{array}{c}X^{2} \\
\text { Probability }\end{array}$ & $\begin{array}{c}\text { Industry } \\
\text { Manufacturing } \\
\text { Insurance }\end{array}$ \\
\hline $\begin{array}{l}\text { Earnings affect dividend payment decisions of } \\
\text { firms }\end{array}$ & 0.277 & $\begin{array}{c}\text { Banking } \\
\text { Manufacturing } \\
\text { Insurance }\end{array}$ \\
\hline $\begin{array}{l}\text { Level of current earnings affect payment } \\
\text { dividend decisions of firms }\end{array}$ & 0.241 & $\begin{array}{c}\text { Banking } \\
\text { Manufacturing } \\
\text { Insurance }\end{array}$ \\
\hline $\begin{array}{l}\text { Level of expected future earnings affect } \\
\text { dividend payment decisions of firms }\end{array}$ & 0.448 & $\begin{array}{c}\text { Banking } \\
\text { Manufacturing } \\
\text { Insurance }\end{array}$ \\
\hline $\begin{array}{l}\text { Stability of earnings affect dividend payment } \\
\text { decisions of firms }\end{array}$ & 0.609 & $\begin{array}{c}\text { Banking } \\
\text { Manufacturing } \\
\text { Insurance }\end{array}$ \\
\hline $\begin{array}{l}\text { Pattern of past dividends affects dividend } \\
\text { payment decisions of firms }\end{array}$ & 0.202 & $\begin{array}{c}\text { Banking } \\
\text { Manufacturing } \\
\text { Insurance }\end{array}$ \\
\hline $\begin{array}{l}\text { Legal rules and constraints affect dividend } \\
\text { payment decision of firms }\end{array}$ & 0.651 & $\begin{array}{c}\text { Banking } \\
\text { Manufacturing } \\
\text { Insurance }\end{array}$ \\
\hline $\begin{array}{l}\text { Level of reserves affect dividend payment } \\
\text { decisions of firms }\end{array}$ & $* 0.025$ & $\begin{array}{c}\text { Banking } \\
\text { Manufacturing } \\
\text { Insurance }\end{array}$ \\
\hline $\begin{array}{l}\text { Impairment of capital affects dividend } \\
\text { payment decisions of firms }\end{array}$ & 0.243 & $\begin{array}{c}\text { Banking } \\
\text { Manufacturing } \\
\text { Insurance }\end{array}$ \\
\hline $\begin{array}{l}\text { Investment opportunities affect dividend } \\
\text { payment decisions of firms }\end{array}$ & 0.673 & $\begin{array}{c}\text { Banking } \\
\text { Manufacturing } \\
\text { Insurance }\end{array}$ \\
\hline $\begin{array}{l}\text { Liquidity [the availability of cash] affects } \\
\text { dividend payment decisions of firms } \\
\text { dividend payment decisions of firms }\end{array}$ & 0.782 & $\begin{array}{c}\text { Banking } \\
\text { Insurance }\end{array}$ \\
\hline
\end{tabular}

Notes: * Significant at the 0.05 level, respectively

\section{CONCLUSIONS}

This is the first study to investigate the views of respondents from LSM-listed firms about the main factors affecting dividend payment decisions. The results of this survey led to several conclusions. First, the vast majority of respondents believe that dividend payment decisions are an important issue. Second, the most important factors influencing dividend decisions include earnings [level of current earning], Patterns of past dividends, investment opportunities, and liquidity [availability of cash]. Third, the findings indicate no difference in the importance of the dividend factors among industries groups, except the level of reserve. Therefore, the industry type issue appeared to influence the importance that respondents placed on determinants of dividend payment decisions.

\section{Notes:}

1- Many research studies conducted in developed economies mainly the US markets, are analyzed based on large sample and cover long period. 
2- The institutional environment in Libya differs from those in the other countries, in terms of shortage of private firms, a poor of market transparency, lax information disclosure requirements, weak regulations and corporate governance, and government intervention in economic activities.

3- Since dividend behavior being "a cultural phenomenon" [Frankfurter and Wood,1997], there is a lack of public awareness of dividends due to dividend payouts were stopped in all institutions in Libya by law approximately for four decades.

\section{References:}

Agrawal, A. and Jayaraman, N. [1994], The Dividend policies of all-equity firms: A direct test of the free cash flow theory, Managerial and Decision Economics, 15[2], pp. 139-148.

Aivazian, V., Booth, L. and Cleary, S. [2003], Do emerging market firms follow different dividend policies from U.S. Firms?, Journal of Financial Research, 26[3], pp. 371-387.

Al-Kuwari, D. (2009). Determinants of the dividend policy in emerging stock exchanges: the Case of GCC Countries. Global Economy \& Finance Journal, 2(2), pp.38-63.

Al-Malkawi, H.-A.N., Rafferty, M. and Pillai, R. [2010], Dividend policy: A review of theories and empirical evidence, International Bulletin of Business Administration, 9. pp. 171-200.

Aljbiri, A. [2012], The Performance of Libyan stock market, Acta Universities Agriculture et Silviculturae Mendelianae Brunensis, 60[7], pp. 27-38.

Alli, K.L., Khan, A.Q. and Ramirez, G.G. [1993], Determinants of corporate dividend policy: A Factorial analysis, The Financial Review, 28[4], pp. 523-547.

Alzomaia, T. and Al-Khadhiri, A. [2013], Determination of dividend policy: The Evidence from Saudi Arabia, International Journal of Business and Social Science, 4[1], pp. 181-192.

Al-Deehani, Talla..M. [2003], Determinants of dividend policy: The case of Kuwait, Journal of Economic and Administrative Sciences, 19[2], pp. 59-76.

Al-Twaijry, Abdulrahman [2007], Dividend policy and payout ratio: Evidence from the Kuala Lumpur stock exchange, The Journal of Risk Finance, 8[4], pp. 349-363.

Archold, S. and Vieira, E.F.S. [2010], Corporate dividend policies in bank based and market based systems: survey evidence from UK and Portugal, Portuguese Journal of Management studies, XV[1], pp.35-63.

Asquith, P. and Mullins, D.W. [1986], Signaling with dividends, stock repurchases, and equity issues, Financial Management, 15[3], pp. 27-44.

Asquith, P. and Mullins, Jr., D.W. [1983], The impact of initiating dividend payments on shareholders' wealth, The Journal of Business, 56[1], pp. 77-96.

Baker, H.K., Chang, B., Dutta, S. and Saadi, S. [2012], Why firms do not pay dividends: The Canadian experience, Journal of Business Finance \& Accounting, 39 [9-10], pp. 1330-1356.

Baker, H.K., Farrelly, G.E. and Edelman, R.B. [1985], A Survey of management views on dividend policy, Financial Management, 14[3], pp. 78-84.

Baker, H.K. and Jabbouri, I. [2016], How Moroccan managers view dividend policy, Managerial Finance, 42[3], pp. 270-288.

Baker, H.K. and Kapoor, S. [2015], Dividend policy in India: New survey evidence, Managerial Finance, 41[2], pp. 182-204.

Baker, H.K., Mukherjee, T.K. and Paskelian, O.G. [2006], How Norwegian managers view dividend policy, Global Finance Journal, 17[1], pp. 155-176.

Baker, H.K. and Powell, G.E. [2000], Determinants of corporate dividend policy: A survey of NYSE firms, Financial Practice and Education, 10[1], pp. 29-40.

Baker, H.K. and Powell, G.E. [2012], Dividend policy in Indonesia: Survey evidence from executives, Journal of Asia Business Studies, 6[1], pp. 79-92.

Baker, H.K., Saadi, S., Dutta, S. and Gandhi, D. [2007], The Perception of dividends by Canadian managers: New survey evidence, International Journal of Managerial Finance, 3[1], pp. 70-91. 
Baker, H.K., Veit, E.T. and Powell, G.E. [2001], Factors influencing dividend policy decisions of Nasdaq firms, The Financial Review, 36[3], pp. 19-38.

Baker, M. and Wurgler, J. [2004a]. A Catering theory of dividends. The Journal of Finance, 59[3], pp.1125-1165.

Baker, M., Mendel, B. and Wurgler, J. [2015], Dividends as reference points: A behavioral signaling approach, Review of Financial Studies, pp. 1-41.

Ballantine, H.W. and Hills, G.S. [1935], Corporate capital and restrictions upon dividends under modern corporation laws, California Law Review, 23[3], pp. 229-263.

Bancel, F., Mittoo, U.R. and Bhattacharyya, N. [2005], Cross-country determinants of payout policy: A survey of European firms, SSRN Electronic Journal, pp. 1-45.

Benartzi, S., Michaely, R. and Thaler, R. [1997], Do changes in dividends signal the future or the past?, The Journal of Finance, 52[3], pp. 1007-1033.

Benzinho, J.M. [2004], A survey of management views on corporate dividend policy in Portugal, Revista de Contabilidade e Comércio, LIX[236], pp. 577-597.

Bhattacharya, S. [1979], Imperfect information, dividend policy, and "the bird in the hand" fallacy, The Bell Journal of Economics, 10[1], pp. 259-270.

Bishop, S.R., Harvey, R.C., Robert, W.F. and Garry, J.T. [2000], Corporate Finance. 5th ed. Sydney: Prentice Hall Inc.

Boldin, R. [1995], Bank dividend policy as a signal of bank quality, Financial Services Review, 4[1], pp. 1-8.

Brav, A., Graham, J.R., Harvey, C.R. and Michaely, R. [2005], Payout policy in the 21st century, Journal of Financial Economics, 77[3], pp. 483-527.

Brittain, J.A. [1964], The Tax structure and corporate dividend policy, American Economic Review, 54[3], pp. 272287.

Chang, R.P. and Rhee, S.G. [1990], The Impact of personal taxes on corporate dividend policy and capital structure decisions, Financial Management, 19[2], pp. 21-31.

Chiang, K., Frankfurter, G.M., Kosedag, A. and Wood, B.G. [2006], The Perception of dividends by professional investors, Managerial Finance, 32[1], pp. 60-81.

Crutchley, C.E. and Hansen, R.S. [1989], A Test of the agency theory of managerial ownership, corporate leverage, and corporate dividends, Financial Management, 18[4], p. 36.

Deangelo, H., Deangelo, L. and Stulz, R. [2006], Dividend policy and the earned/contributed capital mix: A test of the life-cycle theory, Journal of Financial Economics, 81[2], pp. 227-254.

Denis, D.J. and Sarin, A. [1994], The Information content of dividend changes: Cash flow signaling, overinvestment, and dividend Clienteles, The Journal of Financial and Quantitative Analysis, 29[4], pp. 567-587.

Denis, D. and Osobov, I. [2008], Why do firms pay dividends? International evidence on the determinants of dividend policy, Journal of Financial Economics, 89[1], pp. 62-82.

Easterbrook, F.H. [1984], Two agency-cost explanations of dividends, American Economic Review, 74[4], pp. 650-659.

Edweib, A.K.S. [2013], Stock market and economic growth in Libya, IOSR Journal of Economics and Finance, 2[1], pp. 43-51.

El Sady, H., Hamdi, H. and Al Shammari, T. [2012], Dividend policies in an emerging market, SSRN Electronic Journal, pp. 1-19.

Elton, E. and Gruber, M. [1970]. Marginal Stockholder Tax Rates and the Clientele Effect. The Review of Economics and Statistics, 52[1], pp.68-74.

Fama, E.F. and Babiak, H. [1968], Dividend policy: An empirical analysis, Journal of the American Statistical Association, 63[324], pp. 1132- 1161.

Fama, E.F. and French, K.R. [2000], Forecasting profitability and earnings, The Journal of Business, 73[2], pp. 161175.

Fama, E.F. and French, K.R. [2002], Testing trade-off and Pecking order predictions about dividends and debt, Review of Financial Studies, 15[1], pp. 1-33. 
Forti, C.A.B., Peixoto, F.M. and Alves, D.L. [2015], Determinant factors of dividend payments in brazil, Revista Contabilidade \& Finanças, 26[68], pp. 167-180.

Frankfurter, G.M. and Wood, W., Jr. [1997], The Evolution of corporate dividend policy, Journal of Financial Education, [23], pp. 16-33.

Frankfurter, G.M., Kosedag, A., Chiang, K., Collison, D., Power, D.M., Schmidt, H., So, R. and Topalov, M. [2004], A comparative analysis of perception of dividends by financial managers, Research in International Business and Finance, 18[1], pp. 73-114.

Gitman, L.J. and Madura, J. [2000], Introduction to finance: Study guide. United States: Addison Wesley.

Glen, J., Karmokolias, Y, M., R., and S., S., S. [1995], Dividend policy and behavior in emerging markets, IFC Discussion Paper, 26[www.ifc.org].

Gordon, M. [1959]. Dividends, Earnings, and Stock Prices. The Review of Economics and Statistics, 41[2], pp.99-105. Grullon, G., Michaely, R. and Swaminathan, B. [2002], Are dividend changes a sign of firm maturity?, The Journal of Business, 75[3], pp. 387-424.

Gugler, K. and Yurtoglu, B.B. [2003], Corporate governance and dividend pay-out policy in Germany, European Economic Review, 47[4], pp. 731-758.

Higgins, R.C. [1972], The corporate dividend-saving decision, The Journal of Financial and Quantitative Analysis, 7[2], pp. 1527-1541.

Ho, H. [2003], Dividend policies in Australia and Japan, International Advances in Economic Research, 9[2], pp. 91100 .

Holder, M.E., Langrehr, F.W. and Hexter, J.L. [1998], Dividend policy determinants: An investigation of the influences of Stakeholder theory, Financial Management, 27[3], pp. 73-82.

Hossain, F., Sheikh, R. and Akterujjaman, S.M. [2014], Impact of firm specific factors on cash dividend payment decisions: Evidence from Bangladesh, International Review of Business Research Papers, 10[2], pp. 62-80.

Hsiao, Y.-J.and Tseng, Y.-W. [2016], Bank Capital Regulation and Dividend Policy, Journal of Financial Studies, 24[3], pp. 1-26.

Jensen, G.R., Solberg, D.P. and Zorn, T.S. [1992], Simultaneous determination of insider ownership, debt, and dividend policies, The Journal of Financial and Quantitative Analysis, 27[2], pp. 247-263.

Jensen, M.C. [1986], Agency cost of free cash flow, corporate finance, and takeovers, American Economic Review, 76[2], pp. 323-329.

Jensen, M.C. and Meckling, W.H. [1976], Theory of the firm: Managerial behavior, agency costs and ownership structure, Journal of Financial Economics, 3[4], pp. 305-360.

John, A.O. [2013], Managers' perception of factors influencing dividends decision in Nigeria, International Journal of Advances in Management and Economics, 2[2], pp. 135-140.

John, K. and Williams, J. [1985], Dividends, dilution, and taxes: A signalling equilibrium, The Journal of Finance, 40[4], pp. 1053-1070.

Kanwal, A. and Kapoor, S. [2008], Determinants of dividend payout ratios: A Study of Indian Information Technology Sector, International Research Journal of Finance and Economics, [15], pp. 63-71.

Khan, N. [2001], Dividend policy and the stock market reaction to dividend announcements in Pakistan Ph.D. dissertation.

Kumar, B.R. and Waheed, K.A. [2015], Determinants of dividend policy: Evidence from GCC market, Accounting and Finance Research, 4[1], pp. 17-29.

Lintner, J. [1956], Distribution of incomes of corporations among dividends, retained earnings, and taxes, The American Economic Review, 46[2], pp. 97-113.

Manos, R. [2001], Capital structure and dividend policy: Evidence from emerging markets. Ph.D. thesis. The University of Birmingham.

Manos, R. [2003], Dividend policy and agency theory: Evidence from Indian firms, South Asia Economic Journal, $4[2]$, pp. 275-300.

Mayne, L.S. [1980], Bank dividend policy and holding company affiliation, The Journal of Financial and Quantitative Analysis, 15[2], pp. 469-480. 
McCabe, G.M. [1979], The empirical relationship between investment and financing: A new look, The Journal of Financial and Quantitative Analysis, 14[1], p. 119.

Mehta, A., Hashmi, I. and Irshad, A. [2014], Determinants of corporate dividend policy: An Empirical study of banking sector of Pakistan, Interdisciplinary Journal of Contemporary Research in Business, 5[11], pp. 360-369.

Miller, M.H. and Modigliani, F. [1961], Dividend policy, growth, and the valuation of shares, The Journal of Business, 34[4], pp. 411-433.

Miller, M.H. and Rock, K. [1985], Dividend policy under asymmetric information, The Journal of Finance, 40[4], pp. 1031-1050.

Miller, M. and Scholes, M. [1978]. Dividends and taxes. Journal of Financial Economics, 6[4], pp.333-364.

Miller, M. and Scholes, M. [1982]. Dividends and taxes: Some Empirical Evidence. Journal of Political Economy, 90[6], pp.1118-1141.

Mizuno, M. [2007], Payout policy of Japanese firms: analysis on the survey of four industries listed on the Tokyo stock exchange, Pacific Economic Review, 12 [5], pp. 631-650.

Mooi , Erik. and Sarstedt, Marko. [2011], A Concise Guide to Market Research: The process, data, and methods using IBM SPSS statistics, Springer Heidelberg Dordrecht London New York.

Myers, S.C. [1977], Determinants of corporate borrowing, Journal of Financial Economics, 5[2], pp. 147-175.

Myers, S.C. [1984], The capital structure puzzle, The Journal of Finance, 39[3], pp. 575-592.

Myers, S.C. and Majluf, N.S. [1984a], Corporate financing and investment decisions when firms have information that investors do not have, Journal of Financial Economics, 13[2], pp. 187-221.

Naser, K., Nuseibeh, R. and al-Kuwari, D. [2004], Dividend policy of companies listed on emerging stock exchanges: evidences from the banking sector of the Gulf Co-operation Council [GCC], The Middle East business and economic review, 16, pp. 1-14.

Naser, K., Nuseibeh, R. and Rashed, W. [2013], Managers' perception of dividend policy: Evidence from companies listed on Abu Dhabi securities exchange, in Business Management and Economics, 1[1], pp. 001-012.

Pourheydari, O. [2009], A survey of management views on dividend policy in Iranian firms, International Journal of Islamic and Middle Eastern Finance and Management, 2[1], pp. 20-31.

Pruitt, S.W. and Gitman, L.J. [1991], The interactions between the investment, financing, and dividend decisions of major U.S. Firms, The Financial Review, 26[3], pp. 409-430.

Rahman, M.M. [2015], Managers' perception towards dividends and dividend policy-Evidence from Bangladesh, Journal of Financial Risk Management, 04[03], pp. 143-157.

Rozeff, M.S. [1982], Growth, beta and agency costs as determinants of dividend payout ratios, Journal of Financial Research, 5[3], pp. 249-259.

Shevlin, T. [1982, Accounting \& Finance, 22[1], pp. 1-22.

Smith, C.W. and Watts, R.L. [1992], The investment opportunity set and corporate financing, dividend, and compensation policies, Journal of Financial Economics, 32[3], pp. 263-292.

Szomko, N. [2015], Investor reaction to information on final dividend payouts on the Warsaw stock exchange - an event study analysis, International Journal of Management and Economics, 45[1], pp. 127-146.

Ward, M. and Price, A. [2006], Turning vision into value: Corporate finance for non-financial executives. Pretoria, South Africa: Van Schaik. 